\title{
O DIREITO DE MATAR A PARTIR DO PENSAMENTO DE PETER SINGER
}

\section{THE RIGHT TO KILL FROM PETER SINGER'S THOUGHT}

\begin{abstract}
"Em todas as sociedades que conhecemos tem havido alguma forma de proibição de se tirar a vida de outros seres. [...] Contudo, o que tem diferenciado as sociedades é algo que se pode explicitar através de uma pergunta: quem, exatamente, é protegido?" (Peter

Singer)
\end{abstract}

José Soares das Chagas ${ }^{1}$

\section{RESUMO.}

O presente artigo tem como finalidade discutir a questão do direito à vida. Trata-se de uma abordagem crítica de análise conceitual, que se apoia no pensamento ético do professor da Universidade de Princeton, Peter Singer. Com efeito, abordaremos a tese da sacralidade da vida humana (na sua pretensão em se justificar mediante o conceito de pessoa) como um pensamento que delimita fragilmente a fronteira moral. Deste modo, privilegiaremos o ser senciente como ponto de partida da consideração moral da igualdade de interesses e direitos. Com isso, pretendemos construir uma base ética para discussão e apreciação de casos concretos que não incorra em atitudes racistas, sexistas e nem especistas.

PALAVRAS-CHAVE: Igualdade. Matar. Sacralidade da vida humana. Senciente.

\section{ABSTRACT.}

This article aims to discuss the issue of the right to life. It refers to a conceptual analysis of critical approach, which is based on the ethical thinking of the Princeton University Professor, Peter Singer. In fact, the sacredness of human life thesis will be discussed (in its claim to justify itself based upon the concept of person) as a thought that feebly delimits the moral boundary. Thus, the sentient being will be set as the starting point of the moral consideration of equal rights and interests. Therefore, an ethical basis for discussion and assessment of specific cases, which do not incur racist, sexist or speciesist attitudes, is intended to be built.

KEY-WORDS: Equality. To kill. Sacredness of human life. Sentient.

\footnotetext{
${ }^{1}$ Professor de Filosofia da Universidade Federal do Tocantins
} 


\section{INTRODUÇÃO}

Quando nos pomos a questão de subtrair a vida de outro, a primeira reação que geralmente nós (homens e mulheres considerados comuns) temos, é de ojeriza. "Ninguém deveria ter o direito de matar o próximo, porque a vida é sagrada." Este tipo de sentimento e raciocínio espontâneo encobre, no entanto, as reais razões de sermos tão avessos a este gênero de atitude radical. Primeiro, porque nunca se extinguiu em nossa sociedade ocidental este direito; e, também, porque nem mesmo o mais completo altruísta, ou a moral mais deontológica ou eivada de nobreza heroica, descarta que, em certas circunstâncias, matar não é errado. E não só não é errado, mas é até recomendado para certos contextos existenciais, como a legitima defesa e o direito à guerra.

\section{I - AS MORAIS E O DIREITO À VIDA (OU SERIA À MORTE?)}

O direito à guerra (ou como os cristãos e muçulmanos preferem chamar, a "guerra justa/santa") é um exemplo de como as morais que propugnam o heroísmo ético como ideal de vida estão abertas a orientar seus seguidores acerca da justeza de matar. Entre os cristãos esta doutrina é filosófica e teologicamente formulada por Tomás de Aquino, para o qual a Lei Natural, ${ }^{2}$ ou aquilo que podemos individuar racionalmente da ordem da natureza criada, fornece o critério válido para julgar acerca da iniquidade ou correção das leis da cidade; de modo que, em determinadas circunstâncias, deve-se declarar guerra a povos iníquos ${ }^{3}$ ou mesmo deflagrar a

\footnotetext{
${ }^{2}$ Embora o termo não apareça explicitamente na Bíblia, muitos estudiosos afirmam que ela está implícita no discurso de Paulo em que conclui pela culpa dos pagãos que não conheceram a Cristo. Com feito, ela fala de uma lei inscrita no coração e diz que a natureza revela a grandeza de quem o criou: "Quando Pagãos, sem ter lei, fazem naturalmente o que a lei ordena, eles próprios fazem às vezes da lei. Mostram que a obra exigida pela está inscrita em eu coração; a sua consciência dá igualmente testemunho disso, assim como os seus julgamentos interiores que sucessivamente os acusam e os defendem" (Rm 2, 14-15. TEB). Observação: Muitas informações desta e outras notas de rodapé, foram baseadas no seguinte artigo: CHAGAS, J.S. Os direitos humanos e a ética social cristã. Disponível em: http://www2.ifsp.edu.br/edu/prp/sinergia/complemento/sinergia 2014 n3/pdf s/segmentos/artigo 06 v15 n3.pdf. Acessado em: 21 de Setembro de 2016.

${ }^{3}$ Para o doctor angelicus, há três critérios que indicam a justeza da deflagração de uma guerra: ser feita por quem tem a autoridade do governo da multidão (exclui-se os particulares); ter uma causa justa; e uma reta intenção: AQUINO, TOMÁS. Suma Teológica, II-II, q. 40, a. 1. Disponível em:
} 
desobediência e a guerra civil a um governo injusto e tirânico, desde que haja cessado todos os outros possíveis meios pacíficos. Em relação ao Islã, o tema da jirard parece ser mais popular por se tratar de povos que nasceram em meio a conflitos bélicos e por causa da constante exposição nos meios de comunicação de atos terroristas e conflitos no Oriente Médio. Na verdade, embora justifique o conflito armado, o mundo muçulmano é bem injustiçado ao ser visto como um povo violento, em contraste com os cristãos, que seriam um povo pacífico. O Alcorão, como fonte da moralidade muçulmana, é um testemunho vivo de que a violência não faz parte da essência ética do Islã. Basta observar que nas passagens onde se trata da guerra, a orientação prática lá contida é a de que se deve evitar por todos os meios o conflito armado; porém se, por alguma razão, se se encontrarem na iminência de serem dominados por outros povos, que lhes imporão o jugo da escravidão e a ignomínia da infidelidade a Alla, o Deus cheio de misericórdia e compaixão, então se deve tomar as armas e fazer a jirard. ${ }^{4}$

Assim, neste nível de raciocínio, as morais islâmicas e cristãs se encontram dando status de santo a quem, em uma guerra justa tira a vida do inimigo iníquo; ou em outras palavras: o herói, o santo e o piedoso passa a ser quem mata e não quem dá a outra "face a maltratar". E se nem todos os soldados destas expedições de fé podem ser elevados ao nível de heroísmo moral, no mínimo não poderão ser julgados pecadores por terem matado, já que apenas cumpriram seu dever sagrado.

Afigura-se-nos aqui que a nossa reação espontânea em relação ao direito de matar não se coaduna com nossa concepção do valor da vida como absoluta, pois

https://sumateologica.wordpress.com/2009/11/18/tomas-responde-existe-guerra-justa-ou-guerrear-esempre-um-pecado. Acessado em: 20 de Setembro de 2016.

\footnotetext{
${ }^{4}$ Em princípio, o termo jirard não significa guerra, mas "esforço" ou empenho em melhor a si mesmo numa espécie de combate interior (jirard maior) ou em propagar a fé islâmica (jirard menor. No entanto, propagou-se a ideia de que a fé muçulmana é afeita a guerra armada mera e simplesmente e, por isso, essa palavra passou a ter o sentido bélico. No entanto, o Alcorão não prescreve a guerra por causa da sede sangue ou por desconsideração a vida e as convicções do outro; o que faz, na verdade, é compreende-la como uma reação inevitável frente a um ataque injusto, recomendando inclusive que se mantenha a paz e não use da violência se antes não foi atacado. Se ocorre o indesejado, aí deve-se combater como uma legitima defesa para que não venha ocorrer um mal maior como ser obrigado a idolatria. A piedade, porém, deve prevalecer: "E combatei pela causa de Deus, os que vos combatem. Mas não sejais os primeiros a agredir. Deus não ama os agressores. [...] Se desistirem, lembrai-vos de que Deus é clemente e misericordioso. Combatei-vos até que não haja mais idolatria e que prevaleça a religião de Deus. Se detiverem sua hostilidade, detende-vos, exceto contra os iníquos". O ALCORÃO. Trad. Mansour Challita. Rio de janeiro: Associação Cultural Internacional Gibran, sd, pp. 16-17 (Suratra 2, 190-192).
} 
até mesmo para aqueles que mais a defendem, haverá sempre situações em que matar será eticamente desejável.

Ora, poder-se-ia então objetar-nos que a circunstância que citamos acima é apenas um extremo e que o normal é que a moralidade cristã leve ao testemunho pacífico da sua concepção de amor e fé; ou seja, de que o natural é que o mártir, ou aquele que prefere morrer a matar, seja considerado ideal de vida para os outros. Realmente, para a cultura judaico-cristã será sempre mais nobre morrer por uma causa do que matar por ela; no entanto, isso não nega o fato de que este nível de heroísmo não é exigido como regra do homem e da mulher comuns, mas apenas de certas personalidades. No fundo, esta orientação moral, diante de uma vida que está na iminência de ser arrebatada por outra, dirá que se deve optar de fato pela vida, e a sua própria vida está em primeiro lugar dentre aquelas que devem ser defendidas. Assim, o direito de matar está assegurado até mesmo na cultura pretensamente mais pacifista possível.

Citar e dar ênfase a cultura judaico-cristã é bem adequada a esta questão por considerarmos a nossa civilização ocidental como sendo filha de uma laicização dos princípios éticos constituídos no interior dela ao longo de centena de anos. Dentre estas diretrizes éticas se encontra o da "sacralidade da vida", que - embora, hoje em dia, seja defendida por filosofias não religiosas e esteja sacramentada nas diversas constituições modernas - é sem dúvida fruto maduro de nosso "ateísmo cristão". Basta lançar um olhar para outras matrizes culturais para se perceber isso. Haja vista as comunidades tribais para quem era interditada a morte de membros da mesma etnia, mas aos quais não era proibida a morte de membros de outras. Entre os gregos, a ética agônica do kalós kaí agathós levava a morte de crianças que nasciam deformadas. Os recém-nascidos deficientes eram levados para o alto das montanhas geladas e lá eram abandonadas para morrer. A nação Guarani, da época das missões jesuíticas, também tinha como prática matar a segunda criança (a própria mãe matava-a se viesse a nascer), para garantir que não viessem a se tornar escravos; pois, em uma possível fuga de um ataque português ou espanhol, uma mãe teria dificuldade de se locomover com a agilidade necessária para se safar dos colonizadores, se tivesse de carregar duas crianças. No caso dos gregos, a motivação era de evitar uma vida de sofrimentos a quem não encontraria lugar no mundo nem mesmo como escravo. 
Com o passar do tempo, as práticas de matar aqueles que não fossem da mesma tribo se estendeu para os do mesmo Estado e, hoje em dia, se tem como civilizadas aquelas sociedades que assumem secularmente o princípio da "sacralidade da vida". Esta diretriz moral tem sua base teórica nos ensinamentos religiosos, mormente cristãos. Como acreditam em uma vida após a morte acompanhada de gozo ou sofrimentos eternos, matar é antecipar uma realidade para a qual o indivíduo não terá mais opção.

Tomás de Aquino, o doctor angelicus dos católicos, embasa a mesma noção metafísico-religiosa a partir da ideia do direito de propriedade (SINGER, 1993, p. 99). Ora, só ao dono de um escravo, em sua época, era dada a prerrogativa de retirar a vida de seu servo, uma vez que lhe pertencia como um objeto ou um instrumento de trabalho. Outrossim, como todos os humanos são criaturas de Deus, e a ele lhes pertencem como propriedade, matar alguém é o mesmo que cometer um crime contra a própria divina.

Hodiernamente, as justificativas mudaram, pois não se faz menção a uma pretensa realidade divina, mas a noção moral permanece a mesma da santidade divina. E é esta mentalidade religiosa, em roupagens seculares, que direciona os diplomas normativos modernos. Porém, não nos iludamos: a vida não é tão absoluta como se faz parecer pela força retórica com a qual é propugnada nos diversos discursos morais. E a prova disso é a licença religiosa e legal de matar em guerra, como já falamos, e a autodefesa ou legitima defesa. Com efeito, em certas circunstâncias - em que a única maneira de preservar a vida própria, posta em risco injustamente pela vileza de alguém que quer arrebatá-la - matar torna-se não só um direito como, sobretudo, um dever de autopreservação. ${ }^{5}$

Sendo assim a nossa reação imediata de assombro (e ojeriza) perante o tema proposto, dá lugar ao princípio da realidade, pelo qual sabemos que sempre foi facultado, em certas situações e a certas pessoas, o direito de matar. A esta faculdade ética, nem mesmo as morais religiosas ou pacifistas escapam. Portanto, o problema de poder subtrair a vida de outrem sem se tornar moralmente abjeto ou

\footnotetext{
${ }^{5}$ Reza assim o nosso Código Penal no caput do art. 25: "Entende-se em legítima defesa quem, usando moderadamente dos meios necessários, repele injusta agressão, atual ou iminente, a direito seu ou de outrem". CONSTITUIÇÃO DA REPÚBLICA FEDERATIVA DO BRASIL DE 1988. Código Penal. In: Vade Mecum. 6 ed. São Paulo: Saraiva, 2011.
} 
juridicamente criminoso tem a ver muito menos com um significado metafísico de fundamentação última ou deontológica de um princípio absoluto, do que de um limite social e culturalmente aceito. Vimos rapidamente que nas várias sociedades e morais (como a grega, a dos Guaranis, a dos muçulmanos e a cristã) ter direito a matar diz respeito a quem é protegido: o grego contra o bárbaro; a beleza e a liberdade contra a feiura e a servidão (no caso do kalagathós); a liberdade nos Guaranis; e a fé e a propriedade no caso dos muçulmanos e cristãos.

No fundo, a questão diretiva que conduz todas as motivações para matar ou não matar refere-se à questão da igualdade, pois o problema que se põe é o de saber se há uma linha demarcatória ou uma fronteira moralmente aceita, a partir da qual alguém possa se ver na posição ética de matar ou de ser protegido contra a morte. A questão se põe da seguinte maneira, portanto: quem pode ser considerado igual e, por isso, protegido? E sobre que princípio ético podemos orientar nossas ações em relação à vida e à morte? Não devemos nos esquecer, ao tratar estas questões, que vivemos em uma sociedade laica que põe em suas constituições o princípio da Revolução Francesa "de que todos somos iguais". ${ }^{6}$ Como entender esta igualdade como fronteira moral de proteção ou de arrebatamento violento da vida de outrem?

\section{II - DA IGUALDADE OU DE QUEM DEVE SER PROTEGIDO}

\footnotetext{
${ }^{6}$ As modernas Constituições (dentre elas a brasileira de 1988) trazem em seu seio a consciência de que os direitos individuais conquistados pelas revoluções liberais não são suficientes para garantir um estado de justiça entre as pessoas, uma vez que seu pressuposto é negativo, impondo ao Estado um não fazer. Com a situação deplorável em que se encontraram as populações citadinas dos grandes centros industriais no período da segunda revolução industrial, muitos foram os movimentos que procurarão corrigir isso. O mais radical foi a Revolução Russa, que instituiu a Constituição do Povo Operário, cujos direito fundamentais não eram os individuais, mas os coletivos (os sociais). Poderíamos dizer que esses dois momentos históricos representam gerações de Direitos Humanos, que, longe de se excluírem, se complementam. Indício dessa consciência individual-coletiva é a Declaração dos Direitos Humanos de 1948, que conjuga ambas as espécies de direitos e passa a influenciar mais de uma centena de Estados que a subscrevem. "Ao lado dos direitos individuais que têm por característica fundamental um não fazer ou abster-se do Estado, as modernas constituições impõem aos Poderes Públicos a prestação de diversas atividades, visando o bem-estar e o pleno desenvolvimento em que ela se mostra mais carente de recursos e tem menos possibilidade de conquistá-lo pelo seu trabalho" (BASTOS, 1997, p. 259). A nossa CONSTITUIÇÃO FEDERAL de 1988 pode tranquilamente ser lida sob esta chave de leitura: o art. 5o sintetiza as conquistas individuais das revoluções liberais; e o art. 6으 ao art. 11 condensam os objetivos almejados pelas revoluções socialistas e pela organização dos trabalhadores. (Vide observação da nota de roda-pé 1 , deste artigo).
} 
A questão da igualdade torna-se relevante a esta altura de nossa discussão, porque uma vez já constatado que as sociedades e culturas não passam sem este direito, devemos saber quando ele pode ser exercido sem extrapolar o campo moral, criando preconceitos como racismo, sexismo ou especismo. Sob este prisma, podemos perceber que a problemática por nós chamada de "direito" não é uma discussão primordialmente jurídica (cuja realidade é tanto efeito, como causa), mas ética, porquanto a isonomia é uma questão de justiça; e esta, ao contrário do que comumente se pensa, não tem a ver com diplomas legais ou estruturas judiciais (como tribunais, por exemplo). ${ }^{7}$

A primeira ideia que devemos ter em nossa mente é que aquilo que chamamos Ética é relativo e não relativista. Embora variem de uma cultura para outra, os costumes e as razões para se matar alguém, a decisão de realizar este ato não alcança status de ético por satisfazer um modelo ideal e universal, por um lado; e nem por satisfazer um interesse meramente individual, por outro lado. Ora, a mãe grega antiga, ou a guarani das missões jesuíticas, não satisfaz simplesmente a sua predileção maior por um filho ou o desejo puro e simples de se safar da ignomínia consequente da manutenção de uma vida condenada ao sofrimento. O homembomba, ou outro terrorista qualquer, não comete suicídio e mata outros querendo apenas satisfazer a sua libido eternamente com algumas lindas mulheres no paraíso.

Em todos estes casos relativos a contextos culturais diferentes, o que faz igualmente todas as motivações e comportamentos serem igualmente considerados éticos é o fato de que seus agentes acreditam estar agindo retamente e poderem justificar seus padrões de ação de um ponto de vista que se põe acima do interesse meramente individual. Peter Singer nos expressa isso muito didaticamente no seu livro Ética Prática, o qual é utilizado por ele em suas aulas de Bioética na Universidade de Princeton.

\footnotetext{
${ }^{7}$ Esta diferença e autonomia entre estas esferas foi muito bem apresentada pelo jurista Hans Kelsen, para o qual a esfera jurídica não deveria versar sobre a esfera da moralidade sob pena de estar privilegiando uma moral em detrimento das outras: "A pretensão de distinguir Direito e Moral, Direito e Justiça, sob o pressuposto de uma teoria relativa dos valores, apenas significa que, quando uma ordem jurídica é valorada como moral e imoral, justa ou injusta, isso traduz a relação entre a ordem jurídica e um dos vários sistemas de Moral [...]": KELSEN, Hans. Teoria pura do direito. Trad. João Baptista Machado. São Paulo: Martins Fontes, 2000, p. 75.
} 
Vimos ser necessário admitir que os que sustentam crenças éticas nãoconvencionais estão assim, vivendo de acordo com padrões éticos, se, por alguma razão, acreditam que o seu modo de agir é correto. [...] A idéia de viver de acordo com padrões éticos está ligada à ideia de defender o modo como se vive, de dar-lhe uma razão de ser, de justificá-lo. [...] Podemos ir além. Se devemos aceitar que uma pessoa está vivendo de acordo com padrões éticos, isso deve-se dar com base num certo tipo de justificativa. Por exemplo, uma justificativa exclusivamente em termos de interesse pessoal não pode ser aceita. [...] Para serem eticamente defensáveis, é preciso demonstrar que os atos com base no interesse pessoal não são compatíveis com princípios éticos de base mais ampla, pois a noção de ética traz consigo a ideia de alguma coisa maior que o individual. [...] Devo reportar-me a um público maior. Desde os tempos antigos, os filósofos e os moralistas vem expressando a ideia de que a conduta ética é aceitável de um ponto de vista que é, de certa forma, universal (SINGER, 1993, p.18).

Os critérios apresentados pelo professor e filósofo Peter Singer pretendem inicialmente ser mais uma constatação de um raciocínio moral filosófico do que prescrição de um novo modelo. De fato, desde as orientações mais diversas, como a kantiana, epicurista ou existencialista-sartreana, percebemos que o raciocínio ético pressupõe um ponto de vista de onde se procura abarcar as demais perspectivas individuais. Kant faz isso ao admitir como juízos morais apenas aqueles que, numa situação racional-ideal, todos os agentes pudessem agir em acordo com a máxima erigida individualmente (KANT, 2005, p. 59). Para Epicuro, a sensualidade é um dado primordial, de maneira que o prazer é o critério a ser considerado universalmente (EPICURO, 2002, pp. 38-39). Sartre parte da condição humana de condenação à liberdade como parâmetro para o agir de boa ou má-fé (SARTRE, 2014, p. 22). Enfim, estes são apenas alguns exemplos que nos mostram que, de formas diferentes (e, mesmo às vezes de forma contrária!) o pensamento ou modelo de raciocínio e comportamento moral está ligado à exigência de se levar em consideração os demais sujeitos morais.

Peter Singer cita o raciocínio de Macbeth, de Shakespeare, ${ }^{8}$ ao querer matar o rei Duncan, como um interesse que não pode ser justificado eticamente (SINGER, 1994, p. 18). Porquanto o comportamento e pensamento desta personagem não passam de um desejo que só a si mesmo mensura. Com efeito, o herói shakespeareano diz ser apenas "ambições grandiosas" capazes de justificar um assassinato. Diferentemente de Raskolnikov do Crime e Castigo de Dostoiévski ${ }^{9}$ ou

8 SHAKESPEARE, William. Macbeth. In: Shakespeare: Tragédias: Romeu e Julieta, Macbeth e Otelo. Trad. Beatriz Viegas Farias. São Paulo: Nova Cultural, 1978, (Ato I, cena 5).

${ }^{9}$ DOSTOIÉVSKI, Fiódor. Crime e Castigo. 6ª ed. Trad. Paulo Bezerra. São Paulo, Editora 34, 2009. 
do Abe Lucas do Homem Irracional do Wood Allen. ${ }^{10}$ Ambas personagens se põem do ponto de vista do universo em que verberará suas ações para poder enfim considerar o ato de tirar a vida de outrem algo desejável e de grande nobreza.

Raskolnikov não pensa em matar a velha usurária apenas para evitar a dívida contraída e as consequentes cobranças; resolve matá-la porque ela não passa de "um piolho no mundo", cuja falta não irá diminuir a alegria de ninguém sobre a terra, mas, pelo contrário, diminuirá o sofrimento de muitos. Abe Lucas, ao resolver assassinar o juiz Spangler, que só julgava em favor do seu próprio bolso, trazendo dor e mal-estar aos pobres e indefesos, está crente de que isso não resolverá os problemas da humanidade, mas com certeza (ao menos milionésimamente!) diminuirá o mal ou desprazer no mundo. Ambas personagens justificam moralmente suas ações, embora o neurótico [do] Wood Allen não sofra posteriormente (e, ao contrário, se sinta mais forte e motivado para vida); e o neurótico [do] Dostoiévski sofra e padeça a longo do romance. Todavia, isso não vem ao caso aqui. Comentamos apenas como ilustração. Voltemos, assim, ao que nos interessa: a implicação sobre a igualdade como decorrente do raciocínio ético acerca de quem deve ser protegido.

Quando entendemos que o campo ético diz respeito à ação ou ao comportamento levado ao ponto de vista que ultrapassa o bem meramente individual, compreendemos simultaneamente que todos os envolvidos ou afetados pelas consequências da ação devem ser considerados como iguais. Quando, por exemplo, digo que determinada pessoa por conta de sua cor de pele pode apanhar ou ser morto por ser propriedade de outrem, estou excluindo uma pessoa do meu círculo de consideração ética por conta de um critério arbitrário. Do mesmo modo, se reduzo alguém ao ambiente doméstico ou the nego o direito de votar por conta de seu gênero, estou elegendo um discrimen que não pondera os desejos alheios por serem tidos como de menor monta ou inferiores. Seguindo esta mesma linha de raciocínio, caso se imponha sofrimentos a seres não-humanos, só por não pertencerem à nossa espécie, estou dando a minha dor uma maior importância do que a do outro.

${ }^{10} \mathrm{O}$ homem irracional. Dir. Wood Allen. Perf. Joaquin Phoenix; Emma Stone; Parker Posey. Imagem Filmes, 2015, Film. 
Em todos estes casos de racismo, sexismo ou especismo, a linha demarcatória do pensamento e comportamento, perante seres de outros grupos, foi traçada por exclusão, a partir de critérios particularistas que não conseguem abarcar a todos os envolvidos na ação. O tratamento desprendido assemelha-se ao raciocínio de Macbeth, para o qual os outros não importavam. A ação nestes casos fere a igualdade a partir da qual se deveria apreciar todos os interesses envolvidos. Portanto, matar ou maltratar alguém por ser negro, mulher ou animal não satisfaz as exigências do comportamento e raciocínio éticos por ferir a isonomia.

Ao falarmos da igualdade, como um critério informativo de todo e qualquer outro princípio moral, não estamos nos referindo a uma assertiva factual, biológica ou mesmo social. Se assim pretendêssemos, estaríamos indefesos diante das críticas dos que falam de uma superioridade de uns em relação a outros. De fato, não há como negar que para onde olharmos, só vemos diferenças e "desigualdades". Há pessoas mais altas; outras com maior capacidade de raciocínio matemático; outras com mais sensibilidade poética. Há diferentes capacidades morais e intelectuais; pessoas mais benevolentes e sensíveis; outras mais mesquinhas e insociáveis. Enfim, os assassinatos por racismo, sexismo ou especismo não estão errados por pressuporem diferenças, mas por darem menor monta aos interesses diversos dos seus.

Os defensores de sociedades rigidamente hierárquicas teriam bons argumentos para defender a superioridade de uns em relação a outros, se a igualdade fosse demarcada com base factual. A própria ciência seria uma aliada, já que na sua missão de descrever rigorosamente a realidade natural, poderia dar boas razões falando de inteligências predominantes, de violência ou liderança em determinado gênero; mostrando a divisão social do trabalho como base no critério físico, que originalmente restringiu um sexo às tarefas domésticas. Enfim, como os resultados das ciências mudam, seria um risco procurar balizar a sociabilidade nos resultados de um saber descritivo.

Além do mais, seria uma briga sem fim, e sem esperança de grande sucesso, tentar demonstrar contra a genética que os fatores predominantes nas características sociais são meramente do meio ambiente e da educação. Tal querela e desgaste são desnecessários e vãos, uma vez que a igualdade pressuposta na discussão ética é uma assertiva moral. 


\begin{abstract}
A igualdade é uma ideia moral, não é a afirmação de um fato. Não existe uma razão obrigatória do ponto de vista lógico, para pressupor que uma diferença factual entre duas pessoas justifique diferenças na consideração que damos a suas necessidades e a seus interesses. O princípio da igualdade dos seres humanos não é a descrição de uma suposta igualdade de fato existente entre seres humanos: é a prescrição de como devemos tratar os seres humanos (SINGER, 2010, pp. 8-9).
\end{abstract}

Por igualdade pressupomos um princípio ético e não biológico. Tem a ver com a ponderação pela qual se atribui aos entes envolvidos numa ação igual consideração por seus interesses. Não se trata de uma igualdade matemática, mas de realização de utilidades comuns. Haja vista a banal divisão de alimentos entre duas pessoas. Uma que se alimentou normalmente durante todo o dia e, a outra, que atravessou o dia sem nada comer. A divisão matemática falaria em $50 \%$ para um e $50 \%$ para outro, e teria como resultado uma desigual satisfação do interesse. Portanto, a igualdade ética parte dos interesses dos agentes e procura um modo de satisfação dele sem dar maior peso a um dos envolvidos.

Uma igual consideração do interesse, e não um igual tratamento, é o que se quer entender pelo princípio da igualdade como pressuposto necessário para uma ação ser considerada ética. Isso significa que, ao analisar uma situação onde interesses conflitam a partir de um ponto de vista moral, no qual se atribui igual consideração aos envolvidos (ou atingidos pelas consequências de um determinado ato), quase sempre chegaremos a um tratamento desigual. $E$ isso é o que embasa as proteções ou os direitos diferenciados nos ordenamentos jurídicos dos países considerados modernos. Aqui no Brasil, por exemplo, temos as vagas reservadas para estudantes oriundos do ensino público e para negros nas Universidades Federais. Também se garante uma lei exclusiva para mulheres contendo medidas socioprotetivas e agravantes penais. $E$ isso poderia se estender se falássemos dos idosos e das crianças. Com efeito, é porque são de grupos de naturezas diferentes que eles merecem ser tratados de acordo com suas especificidades.

No que concerne ao nosso tema, o direito de matar, precisamos nos por a questão de qual discrimen poderia satisfazer a exigência de igual consideração aos afetados pela ação de tirar a vida de alguém. Já vimos que nas diferentes culturas e morais as justificativas mudam, porém sem deixar de dar razões a necessidade do ato e de sua justeza e adequação. Em algumas, se proíbe matar os de outras tribos; em outras, os cidadãos ou os senhores, mas não de estes matarem os escravos ou 
os que poderiam vir a ter uma vida escrava ou assemelhada à escravidão (como no caso das crianças guaranis em tempo de fuga e o infanticídio entre os antigos gregos).

No nosso mundo atual, dito civilizado, as diferenças de nações, cor da pele, gênero ou deficiência física já não são mais aceitas como critério de inferioridade (pelo menos não oficialmente!), e, por isso, não se faculta matar pelo fato de a pessoa pertencer a um grupo de características diversas. A linha demarcatória ou a fronteira moral, a partir da qual se considera os interesses como sendo possíveis de serem levados em consideração, é geralmente traçada tendo como critério a noção de humanidade. Aqui, deparamo-nos novamente com a doutrina da "sacralidade da vida", que, como já falamos, é um princípio cristão, hoje secularizado em várias filosofias e em muitas Constituições do nosso mundo moderno e laico.

\section{III - O QUE HÁ DE ERRADO EM MATAR}

Quando por aí se fala que a vida é sagrada, procura-se por meio de força de expressão apenas dizer que a vida humana, e tão somente ela, é especial. Claro está que não se menciona a vida, mera e simplesmente, pois se assim fosse, estes defenderiam a vidas das arvores, dos porcos e da alface, dentre outros seres que poderiam ser considerados vivos. Isso, de certa forma, é um alívio, porque em princípio não precisamos nos enveredar em questões metafísicas (ou mesmo físicas e biológicas) sobre o início e o fim da vida, para sabermos quando é errado matar. Como já dissemos, a doutrina em comento, delimita a fronteira moral por meio da atribuição de um valor inestimável ao fato de alguém pertencer à espécie humana.

Mas o que viria a ser um humano para lhe darmos maior consideração do que aos seres simplesmente sencientes? Basicamente, são dois os sentidos compreendidos por este termo: homo sapiens; e pessoa. O primeiro é um fato meramente biológico e pode ser constatado cientificamente pela verificação de vinte e três cromossomos em uma célula; e qualquer fusão bem-sucedida de um espermatozoide com um óvulo é suficiente para produzir um novo ser desta espécie. Há uma grande quantidade de defensores, sobretudo entre os cristãos hiperortodoxos, para os quais este critério é suficiente para dar a um embrião, ou a um humano desenganado dos médicos e sofrendo horrores, ou a um paciente em 
estado vegetativo, um status de superioridade em relação a qualquer outro ser senciente.

A razão disso tudo, já foi comentada por nós ao mencionarmos o medo dos medievais de condenar ou apressar à condenação eterna, já que uma vez morto, não haveria mais chances de mudar de vida ou de destino. (Porém, nem por isso católicos e evangélicos deixaram de acender algumas fogueiras sagradas para queimar e purgar as almas dos pecadores e lhes conceder a vida eterna num grande gesto de defesa integral da vida humana! Falamos com ironia, obviamente!). No caso dos embriões, a doutrina da vida humana e a interdição de matá-los não advém dos medievais. Eles, inclusive, diga-se de passagem, foram até muito tolerantes a ideia do aborto; pois, como o próprio Tomás de Aquino defendia, a vida humana começa do ponto de vista moral desde o momento em que o corpo é enformado. $E$ isso só se dá com alma individual que, segundo ele, Deus concedia no nascimento.

A proibição do aborto, na verdade, remonta à criação do primeiro microscópio (por Hans Jessen e Antonie Van Leewenhoek, nos séculos XVI e XVII, respectivamente). ${ }^{11}$ Com efeito, ainda muito rudimentar, este aparelho em seu início, ao analisar o esperma, fazia ao observador enxergar os gametas masculinos como se fossem "homúnculos"; que, como o próprio nome indica, eram idênticos a "homenzinhos". Ora, como os espermatozoides foram cientificamente considerados seres humanos, até mesmo espeli-los sem função procriativa tornou-se sinônimo de assassinato (e é, por isso, que até hoje no moderno Catecismo da Igreja Católica, a masturbação é considerada pecado mortal). ${ }^{12} \mathrm{E}$ se os espermatozoides eram considerados já humanos, o que se dirá do embrião ou do feto que, nesta forma de analisar, já eram seres humanos mais desenvolvidos? A tecnologia se desenvolveu, os microscópios possuem maior precisão, a ciência avançou, mas a doutrina da sacralidade da vida para este e outros grupos de cristãos continua a mesma.

\footnotetext{
${ }^{11}$ Muitas destas informações podem ser encontradas neste primoroso manual de Bioética: DURANT, Guy. Introdução Geral à Bioética. História, conceitos e instrumentos. Loyola: São Paulo, 2003.

${ }_{12}$ A definição de pecado mortal no CIC-CATECISMO DA IGREJA CATÓLICA (São Paulo: Loyola, 2000) diz respeito a um ato que se refere à matéria grave, cometido consciente e deliberadamente, segundo o parágrafo 1857 do CIC (p. 497). Já se referindo à masturbação, o CIC 2352, depois de defini-la, diz que se trata de um "[...] ato intrínseca e gravemente desordenado" (p. 609); ou seja, considera-a como pecado mortal, embora mais à frente amenize a partir de fatores subjetivos e sociais (maturidade, contexto social etc).
} 
O segundo sentido para ser humano é o de Pessoa, derivado do latim, "persona", esta palavra referia-se originalmente as máscaras que os atores romanos utilizavam no teatro clássico para mostrar que estavam atuando. Hodiernamente, este termo significa alguém que é agente ou cumpre algum papel social. Diferentemente do sentido meramente biológico do homo sapiens, compreende-se por ser humano um ente que possui algumas características como capacidade de comunicar-se, pensamento, reflexão e, sobretudo, consciência de si ou a faculdade de perceber-se como entidade distinta com passado e futuro. Assim, quando dizemos que alguém é um grande ser humano, ou um ser humano exemplar, ou mesmo desumano, estamos nos referindo a esta segunda significação.

Ora, se possuir uma consciência de si (característica que engloba todas as outras mencionadas) é critério para se conceder a um ser uma predileção e conservar-lhe a vida, então decorre daí duas implicações: 1 - há pessoas nãohumanas como orangotangos, que, mesmo em graus mínimos possuem linguagem e certa capacidade de se reconhecer diante de um espelho; 2 - muitos seres humanos, ou membros da espécie homo sapiens, não são pessoas. Assim, alguém em estado vegetativo ou, mesmo uma criança, não apresentam as características de um ser autoconsciente, não podendo por isso (e isso é chocante!) reivindicar nenhuma superioridade moral em relação a um animal como um gato ou um porco, por exemplo - a não ser que se queira regredir à ideia de que basta pertencer a espécie homo sapiens para se ter o direito de matar os outros seres e de ter a sua vida protegida. Todavia, como já vimos, esta tese não se sustenta.

Não é a linguagem, a inteligência, a cor da pele, o gênero, ou mesmo a pertença a uma espécie específica que demarca a fronteira moral de maneira igualitária, ou seja, de modo a dar o mesmo peso a todos os interesses envolvidos. Pois, se disséssemos, por exemplo, que é a inteligência e a reflexão que fazem uma pessoa superior e eticamente relevante, estes critérios não seriam menos arbitrários do que ser branco, homem ou simplesmente gente; porquanto daríamos as pessoas, que diante de certos tipos de testes de inteligência se sobressaíssem, o direito de matar ou escravizar em detrimento da preferência dos outros.

Uma afirmação ridícula destas mostra como é insuficiente e mesmo inadequado buscar em propriedades da consciência de si a linha fronteiriça para se determinar a relevância moral de um ser e a proteção a ela devida. Não é por ser 
pessoa, ou por ter autoconsciência, que se deve considerar um ser a partir do princípio da igualdade, mas tão somente porque é um ser senciente. É pela sua capacidade de sofrer e de lutar contra a dor e a morte, ou de buscar uma vida prazerosa e satisfatória, que podemos dar a um ser o status moral de proteção e consideração. Com isso, não queremos dizer que demarcar a fronteira ética com outros critérios seja de todo errado, ou que eles não devem ser levados em conta. Todavia estamos apenas afirmando que a senciência é o pré-requisito para todos os outros atributos: a condição primeira para que um ser tenha interesse.

Portanto, não há nenhuma relevância peremptória e exclusivista em se ter consciência de si. Não há, em si, um erro em arrebatar a vida de outrem simplesmente por ele ser pessoa. No entanto, deve-se salientar que sendo um ser senciente os seus interesses devem ser considerados; e aí entra secundariamente este atributo constitutivo do que se entende por humanidade. Ora, a autoconsciência implica em se ter uma vida mental contínua, ou na capacidade de se reconhecer distinto e com existência no tempo. Isso implica que o meu desejo de não sofrer ou de ter uma vida satisfatória está ligada a desejos relativos ao futuro. Haja vista um estudante de Filosofia que pretende poder escrever seu tcc, terminar o seu curso e atuar como professor em colégios e faculdades; ou um estudante de Teatro que sonha em poder atuar em colégios, faculdades e palcos e, quem sabe, fazer novelas e filmes. Enfim, o atributo da consciência de si dá aos interesses dimensões de futuro que devem ser levados em conta pelo princípio da igual consideração exigida pelo raciocínio moral. Porém, aqui nos advém um novo problema: quando sou morto meus desejos relativos ao futuro cessam e, naturalmente, não sofro mais. Posso, então, matar? (Cf. SINGER, 1993, p.100).

A esta indagação o "utilitarismo clássico" (de Bentham, Stuart Mill e Sidgwick $)^{13}$ não encontra nenhuma relevância direta em se matar uma pessoa. Indiretamente, entretanto, pode-se considerar duas boas razões. A primeira diz respeito ao fato de que se qualquer pessoa pode ser morta impunemente, isso acarretará uma comoção social. Ninguém se sentirá seguro, pois sofrerá com a virtualidade e insegurança de poder ser morto a qualquer momento por qualquer motivo. A segunda razão refere-se à diminuição das experiências agradáveis que a

${ }^{13}$ Para uma abordagem mais aprofundada sobre estes autores e o utilitarismo, indicamos a seguinte obra: OLIVEIRA, Manfredo (Org.). Correntes fundamentais da ética contemporânea. $4^{\mathrm{a}}$ ed. Petrópolis, RJ: Vozes, 2009. 
pessoa poderia experimentar. Quando mato um ser humano, impeço que ele continue suas experiências de vida e aumente suas experiências felizes. No fim das contas, esta última razão não seria exclusiva do ser humano, pois "Esta objeção ao assassinato vai aplicar-se a todo e qualquer ser com possibilidade de ter um futuro feliz, independente do fato de ser pessoa" (SINGER, 1993, p. 101).

Eliminada a doutrina da sacralidade da vida, por inconsistência filosófica e moral, parece que o motivo realmente importante, para se considerar errado matar, é o da comoção social e do consequente efeito sobre a vida das demais pessoas. Todavia esta condição desapareceria se um assassinato fosse praticado sem que ninguém soubesse. É o caso dos exemplos que já demos do Raskolnikov e do Abe Lucas. Raskolnikov analisa a importância da velha usurária e vê a vida dela com o mesmo valor de um "piolho no mundo", um ser abjeto, insignificante, que, em nada, demonstra humanidade. Eliminá-la não traria sofrimento a ninguém, pois nem mesmo a irmã da anciã perderia com isso, já que por ela era maltratada. Abe Lucas, por sua vez, torna-se um homem de ação ao dar ao ato de matar o velho juiz iníquo o sentido necessário para construir a sua essência própria (sartreanamente, falando!). Para a personagem do Wood Allen, matar um homem deste tipo, capaz apenas de injustiçar os pobres, não eliminaria o mal, a dor ou a injustiça no mundo, porém, mesmo em nível milionesimal, a diminuiria. O problema seria apenas realizar o ato como um crime perfeito, sem pistas, evidências ou suspeitos sérios. Porém, em ambos os casos, a teoria esbarra com a realidade; e um é pego pela sua própria consciência neurótica; e o outro, pela sua confidente e íntima amiga e aluna, a Jill.

No caso do Homem Irracional do Wood Allen, vale destacar os níveis de raciocínio, crítico e intuitivo, presentes nos diálogos entre o professor de filosofia e sua aluna. O Abe Lucas representa o nível moral crítico e justifica sua ação de matar o juiz Spangler como um ato de grandeza moral, que só terá consequências positivas para o mundo, porquanto tudo foi minuciosamente planejado para que nunca se soubesse quem matou (ou se de fato se tratava de um assassinato ou de uma morte natural). A aluna que descobre tudo, sofre por saber, e permanece no nível intuitivo moral. Ela objeta o pensamento de Abe Lucas dizendo que entende que há boas razões para matar o juiz, e até se alegraria se fosse uma morte natural, mas que sente ser errado matar - e isso basta! 
Os diálogos, e a trama do filme como um todo, corroboram a tese de que, na realidade do cotidiano, o cálculo de todas as circunstâncias e efeitos de uma ação não podem ser precisamente aferidos, pois raciocinamos sempre em condições não ideais (cercado de paixões, disputas, medos, rivalidades e parcialidades). Na sala de aula, em uma conversa aberta e aprofundada em um café, na casa de um amigo, ou mesmo num bar, a elucubração dos efeitos de uma ação em um caso particular é salutar e naturalmente decorrente de um pensamento crítico, não preconceituoso (e inconformado com o óbvio). Porém, nas decisões do cotidiano, o melhor é permanecer nas considerações gerais sobre circunstâncias genéricas, as quais requerem a anuência de que princípios como não mentir, não enganar e não matar, por exemplo, não são bons pelos efeitos sociais destrutivos que tem.

\begin{abstract}
Pode ser que, a longo prazo, cheguemos a melhores resultados - uma maior felicidade geral - se instarmos com as pessoas para que não julguem cada ato individual com o critério de utilidade, mas que, em vez disso, pensem em termos de princípios mais amplos, que venham a abranger todas ou virtualmente todas, as situações com as quais possivelmente venham a deparar-se. [...] o raciocínio moral do dia-a-dia deve ser mais intuitivo. Na vida real, em geral não somos capazes de prever todas as complexidades de nossas escolhas. Simplesmente não é prático tentar calcular, com antecedência, todas as consequências de qualquer opção que fazemos (SINGER, 1993, p. 102).
\end{abstract}

Toda esta problemática decorrente do utilitarismo clássico, para responder a questão do que há de especialmente errado em matar uma pessoa, perde força quando defrontado com o "utilitarismo preferencial". Para esta corrente de raciocínio moral como o próprio nome sugere, os atos são julgados segundo os interesses enquanto manifestam preferências individuais. Deste modo, não importa a tendência de uma ação em aumentar o prazer ou diminuir o sofrimento; ou mesmo de garantir uma satisfação a um maior número de pessoas. A utilidade aqui é vista em termos de preferência, de modo que haverá sempre uma gravidade maior em matar uma pessoa do que outro ser incapaz de se ver no tempo.

\title{
CONCLUSÃO
}

Matar uma pessoa significa não só ignorar o seu interesse em não sofrer, mas desconsiderar tudo o que ela fez e construiu até então, e também frustrar o desejo de continuar existindo. O mal aqui e o erro está em frustrar uma preferência, "[...] a 
menos que essa preferência seja superada, em termos de seu valor, pelas preferências contrárias" (SINGER, 1993, p. 104). Note-se aqui, que a fronteira moral, do matar ou não matar, não foi traçada por uma suposta superioridade ou sacralidade da vida humana, mas pelo princípio de uma igual consideração de interesse, cuja referência é o ser senciente. Assim, como tudo o que viemos falando neste texto tinha por base este tipo de princípio e raciocínio, não vemos necessidade de continuar a explicá-lo.

\section{REFERÊNCIAS}

AQUINO, Tomás de. Suma Teológica. Disponível em: https://sumateologica.wordpress.com/2009/11/18/tomas-responde-existe-guerrajusta-ou-guerrear-e-sempre-um-pecado. Acessado em: 20 de Setembro de 2016.

ALCORÃO. Trad. Mansour Challita. Rio de janeiro: Associação Cultural Internacional Gibran, sd.

BASTOS, Celso Ribeiro. Curso de Direito Constitucional. 18 ed. São Paulo: Saraiva, 1997.

BÍBLIA - Tradução Ecumênica (TEB). 3ª ed. São Paulo: 1994.

BRASIL. CONSTITUIÇÃO DA REPÚBLICA FEDERATIVA DO BRASIL DE 1988. Código Penal. In: Vade Mecum. 6 ed. São Paulo: Saraiva, 2011.

CATECISMO DA IGREJA CATÓLICA. São Paulo: Loyola, 2000.

CHAGAS, J.S. Os direitos humanos e a ética social cristã. Disponível em: http://www2.ifsp.edu.br/edu/prp/sinergia/complemento/sinergia 2014 n3/pdf s/segm entos/artigo 06 v15 n3.pdf. Acessado em: 21 de Setembro de 2016.

DOSTOIÉVSKI, Fiódor. Crime e Castigo. 6a ed. Trad. Paulo Bezerra. São Paulo, Editora 34, 2009.

EPICURO. Carta sobre a felicidade (a Meneceu). Edição bilíngue grego-português, traduzida por Álvaro Lorencini e Enzo Del Carratore. São Paulo: UNESP, 2002.

DURANT, Guy. Introdução Geral à Bioética. História, conceitos e instrumentos. Loyola: São Paulo, 2003.

KANT, Immanuel. Fundamentação da metafísica dos costumes. Trad. Paulo Quintela. Lisboa: Edições 70, 2005.

KELSEN, Hans. Teoria pura do direito. Trad. João Baptista Machado. São Paulo: Martins Fontes, 2000 
SARTRE, Jean-Paul. O existencialismo é um humanismo. Trad. João Batista Kreuch. 4aㅡ ed. Petrópolis: Vozes, 2014.

SHAKESPEARE, William. Macbeth. In: Shakespeare: Tragédias: Romeu e Julieta, Macbeth e Otelo. Trad. Beatriz Viegas Farias. São Paulo: Nova Cultural, 1978.

SINGER, Peter. Ética Prática. Trad. Jefferson Luiz Camargo. São Paulo: Martins Fontes, 1993.

Libertação animal. São Paulo: Wmf Martins Fontes, 2010.

O homem irracional. Dir. Wood Allen. Perf. Joaquin Phoenix; Emma Stone; Parker Posey. Imagem Filmes, 2015, Film.

OLIVEIRA, Manfredo (Org.). Correntes fundamentais da ética contemporânea. 4르 ed. Petrópolis, RJ: Vozes, 2009. 